ROCZNIKI TEOLOGICZNE

Tom LXVI, zeszyt $10-2019$

DOI: http://dx.doi.org/10.18290/rt.2019.66.10-9

EWA KRZYŻAK-SZYMAŃSKA

\title{
DYSFUNKCJONALNE UŻYWANIE TELEFONU KOMÓRKOWEGO WŚRÓD MŁODZIEŻY A KONTROLA RODZICIELSKA
}

\author{
DYSFUNCTIONAL MOBILE PHONE USE AMONG ADOLESCENTS \\ AND PARENTAL CONTROL
}

\begin{abstract}
A b s t r a c t. The dynamic expansion of digital technologies and their more common using in a daily life cause that researchers are thinking of their influence on human development and social functioning. The mobile phone (smartphone) has a special place among these devices which is now used not only for communicational aims but also as a mobile command centre. That is why researchers are trying to explain when mobile phone use becoming dysfunctional and what are the reasons of this state. One of the enviromental factor which have an impact on a addiction development is a parental control made by a mother and a father in the range of mobile phone using by a child. The article presents the researches results of disfunctional mobile phone using by youth, in the context of parental control realised by attendants in the area of new media using. 2657 results of students in the age 12-19 from middle and upper-secondary schools from the silesian voivodeship were analysed. The people choice to the research sample was randommulti-layered. In studies used a Mobile Phone Problem Use Scale for Adolescents (MPPUSA) and a authorial questionnaire. Certified the statistically significiant connection (although weak) between dysfunctional mobile phone using level and realised parental control in the terms of a device use.
\end{abstract}

Key words: technological addictions; problematic mobile phone use; parental control.

Dr Ewa Krzyżak-SzymańsKa - Katedra Bezpieczeństwa Powszechnego, Akademia Wychowania Fizycznego im. Jerzego Kukuczki w Katowicach; e-mail: ewaoliwia36@wp.pl 


\section{WPROWADZENIE}

Świat mediów i nowych technologii cyfrowych ciągle się zmienia. W erze mobilności wśród urządzeń technologicznych szczególne miejsce zajmuje telefon komórkowy, który stał się swoistym „centrum dowodzenia”. Zapewnia on ciągły dostęp do dobrodziejstw technologicznego świata, wypierając coraz to nowe urządzenia $\mathrm{z}$ jego obiegu. Współczesny świat przybiera formę mobilną - nieograniczoną ani miejscem, ani czasem. Badacze ${ }^{1}$ wskazują na wykształcenie się specyficznego, ekologicznego techno-mikrosystemu funkcjonowania człowieka, który może mieć zarówno pozytywny, jak i negatywny wpływ na jego rozwój. W przypadku młodego pokolenia (noszącego miano pokolenia cyfrowego) integralnymi elementami tego systemu są: środowisko rodzinne, szkolne i rówieśnicze. To rodzina, jako grupa pierwotna, odgrywa ważną rolę w rozwoju technologicznym (korzystania z nowych mediów cyfrowych) dzieci. To ona poprzez organizowanie, motywowanie, instruowanie i kontrolowanie korzystania z urządzeń cyfrowych ma wpływ na bezpieczne poruszanie się dzieci w świecie technologii ${ }^{2}$. Dlatego też tak istotna stała się kwestia kontroli rodzicielskiej, która powinna być dla dzieci swoistym drogowskazem w cyfrowym świecie. To dzięki właściwym działaniom rodziców możliwe jest przygotowanie ich do dorosłego życia. Nie bez znaczenia jest też wpływ rodziny na kształtowanie się problemowego używania technologii cyfrowych, w tym telefonu komórkowego czy smartfonu ${ }^{3}$, w szczególności, gdy już dwuletnie dzieci używają tego rodzaju technologii do oglądania bajek i słuchania piosenek. Pedagodzy i psycholodzy wskazują, że nadużywanie telefonu komórkowego może prowadzić do nałogowego korzystania z niego i powodować zakłócenia w funkcjonowaniu społecznym jednostki.

Z prowadzonych na świecie badań wynika, że wśród adolescentów problem ten dotyczy od $5 \%$ do $33 \%$ omawianej grupy wiekowej ${ }^{4}$. W polskich badaniach odnotowano od $2 \%$ do $4 \%$ młodzieży spełniającej kryteria uzależnienia od

${ }^{1}$ G.M. Johnson, K.P. Puplampu, Internet Use during Childhood and the Ecological Techno-Subsystem, „Canadian Journal of Learning and Technology” 2008, nr 34, s. 19-28.

2 G.M. Johnson, Internet Use and Child Development: The Techno-Microsystem, „Australian Journal of Educational \& Developmental Psychology" 2010, nr 10, s. 32-43.

3 E. Krzyżak-Szymańska, Uzależnienia technologiczne wśród dzieci i młodzieży. Teoria, profilaktyka, terapia- wybrane zagadnienia, Kraków: Impuls 2018, s. 85-86.

${ }^{4}$ O. Lopez-Fernandez, L. Honrubia-Serrano, M. Freixa-Blanxart, Prevalence of problematic mobile phone use in British adolescents, „CyberPsychology, Behavior and Social Networking” 2014, nr 17, s. 91-98. 
telefonu komórkowego ${ }^{5}$, a zagrożonych tym zjawiskiem jest około $35 \%$ badanej grupy ${ }^{6}$. Ta różnorodność szacunków wynika $\mathrm{z}$ braku jednolitości wśród badaczy w zakresie m.in. definiowania kryteriów diagnostycznych czy założeń stosowanych skal pomiarowych. Natomiast brak jest badań, które opisują wśród czynników środowiskowych kontrolę rodzicielską używania telefonu komórkowego przez dziecko i jej związek z problemowym korzystaniem z urządzenia. Jedyne badania, które poruszały tę kwestię, to badania zrealizowane przez TNS Polska S.A. ${ }^{7}$, z których wynika, że $1 / 4$ rodziców (tj. 23\% respondentów) stosuje ją wobec dzieci użytkujących smartfony ${ }^{8}$.

Dlatego też zainteresowania autorki skupiły się na określeniu związku dysfunkcjonalnego używania telefonu komórkowego przez młodzież z kontrolą rodzicielską przedmiotowej aktywności. Celem niniejszego artykułu jest próba odpowiedzi na pytanie: czy istnieje statystycznie istotny związek między poziomem dysfunkcjonalnego używania telefonu komórkowego badanych uczniów a sprawowaniem kontroli rodzicielskiej w zakresie użytkowania telefonu komórkowego przez dziecko?

Uszczegółowiając problem, postawiono następujące pytania badawcze:

1. Jaki jest odsetek badanych dysfunkcjonalnie używających telefonu komórkowego?

2. Jaki odsetek rodziców stosuje kontrolę rodzicielską w zakresie używania telefonu komórkowego wobec swoich dzieci?

3. Jakie formy kontroli rodzicielskiej stosują rodzice wobec używania przez swoje dzieci telefonów komórkowych?

4. Czy istnieją różnice w formach kontroli rodzicielskiej w zależności od płci i wieku dziecka?

5. Czy istnieje związek między aktywnościami badanych podejmowanymi za pomocą telefonu komórkowego a występowaniem kontroli rodzicielskiej?

5 B. PawŁowska, E. PotembsKa, Objawy zagrożenia i uzależnienia od telefonu komórkowego mierzonego Kwestionariuszem do Badania Uzależnienia od Telefonu Komórkowego, autorstwa Potembskiej i Pawłowskiej, u młodzieży w wieku od 13 do 24 lat, „Current Problems of Psychiatry” 2011, nr 12, s. 443-446; E. KRZYŻAK-SzYMAŃSKA, Norma i patologia w użytkowaniu przez digital natives nowych technologii cyfrowych, w: Tváre l'udského života. Vybrané problémy, red. W. Kądziołka, Ružomberok: Verbum-vydavatel'stvo KU 2015, s. 129-68; M. DęBSKi, Natogowe korzystanie z telefonów komórkowych. Raport z badań, Gdańsk: Fundacja Dbam o swój zasięg 2016.

${ }^{6}$ B. PawŁowsKa, E. Potembska, Objawy zagrożenia i uzależnienia od telefonu komórkowego, s. 443.

7 TNS Polska S.A., Rodzice i dzieci wobec zagrożeń dzieci w Internecie, Warszawa: Fundacja Orange 2016.

8 Tamże, s. 12. 


\section{ASPEKTY TEORETYCZNE REALIZOWANYCH BADAŃ}

\subsection{DYSFUNKCJONALNE KORZYSTANIE Z TELEFONU KOMÓRKOWEGO - ASPEKTY DEFINICYJNE}

W literaturze przedmiotu dysfunkcjonalne korzystanie z telefonu komórkowego identyfikowane jest m.in. za pomocą pojęć: problemowe korzystanie ${ }^{9}$, nadmierne używanie $^{10}$, uzależnienie ${ }^{11}$ i nałogowe korzystanie ${ }^{12}$. W prezentowanych badaniach posłużono się kategorią analityczną „dysfunkcjonalne korzystanie z telefonu komórkowego". Jest to termin szerszy niż problemowe używanie telefonu komórkowego. Obejmuje on:

- nadużywanie urządzenia, chrakteryzujące się określoną liczbą symptomów diagnostycznych, przewidzianych dla występowania danego zaburzenia (uzależnienia),

- zagrożenie nadużywaniem, które przejawia się tylko niektórymi symptomami chrakteryzującymi nałóg i nie spełnia wszystkich wymaganych kryteriów diagnostycznych ${ }^{13}$.

Problemowe korzystanie z telefonu komórkowego dotychczas nie zostało ujęte w żadnej klasyfikacji medycznej, a do oceny nałogu wykorzystuje się zwykle ogólne kryteria diagnostyczne uzależnień ${ }^{14}$.

A. Bianchi i J.G. Philips ${ }^{15}$ wyróżnili następujące kryteria diagnostyczne nałogowego używania telefonu: (1) potrzebę korzystania przez coraz dłuży czas, aby osiągnąć podobny stopień satysfakcji z jego użytkowania; (2) używanie telefonu komórkowego jako sposobu na ucieczkę od problemów lub dla poprawy złego nastroju; (3) poczucie zagubienia, przygnębienia, niepokoju, poirytowania, pogorszenia nastroju w sytuacji próby ograniczania korzystania z urządzenia; (4) częste

9 P. IzDebsкi, M. KотүŚKo, Problemowe korzystanie z nowych mediów, w: Zaburzenia uprawiania hazardu i inne tak zwane nałogi behawioralne, red. B. Habrat, Warszawa: Instytut Psychiatrii i Neurologii 2016, s. 219-304.

${ }^{10}$ S. Pourrazavi, H. Allahverdipour, M.A. Jafarabadi, H. Matlabi, A socio-cognitive inquiry of excessive mobile phone use, „Asian Journal of Psychiatry” 2010, nr 10, s. 84-89.

11 Y.-H. Lin, L.-R. Chang, Y.-H. Lee, H.-W. Tseng, T.B.J. Kuo, S.-H. Chen, Development and Validation of the Smartphone Addiction Inventory (SPAI), „PLoS ONE” 2014, nr 9(6), s. e98312.

12 S. Sahin, K. Ozdemir, A. Unsal, N. Temiz, Evaluation of Mobile Phone Addiction Level and Sleep Quality in University Students, „Pakistan Journal of Medical Sciences” 2013, nr 29, s. 913-918.

13 E. KRZYŻAK-SZYMańSKA, Uzależnienia technologiczne, s. 102.

14 I. Grzegorzewska, L. Cierpiatkowska, Uzależnienia behawioralne, Warszawa: Wydawnictwo Naukowe PWN 2018, s. 239.

15 A. Bianchi, J.G. Phillips, Psychological predictors of problem mobile phone use, „Cyberpsychology \& Behavior” 2005, nr 8, s. 39-51. 
przekraczanie planowanego wcześniej czasu przeznaczanego na użytkowanie telefonu; (5) nieudane próby ograniczania bądź zaprzestania użytkowania; (6) ukrywanie przed rodziną i przyjaciółmi skali zaangażowania w wykorzystywanie telefonu ${ }^{16}$.

Y.H. Lin i współpracownicy w diagnozie omawianego problemu, rozpatrując użytkowanie przez człowieka smartfona, posłużyli się natomiast kryteriami zgrupowanymi w trzech obszarach:

1. Dezadaptacyjny wzorzec korzystania ze smartfona prowadzący do istotnych klinicznie upośledzeń (impairment) lub dystresu. W tym obszarze wyróżniono takie czynniki, jak: (1) zaabsorbowanie używaniem smartfona przez cały dzień czy nawracające niepowodzenia ograniczania korzystania z niego, (2) wzrost częstości korzystania z urządzenia celem uzyskania dotychczasowej satysfakcji, (3) pojawienie się zaburzeń nastroju, lęków lub irytacji w sytuacji niekorzystania z telefonu, (4) używanie urządzenia dłużej niż pierwotnie planowano, (5) nieudane próby lub prześladujące pragnienie zaprzestania lub ograniczenia korzystania z urządzenia, (6) wzrost czasu poświęcanego na używanie telefonu i/lub nadmiernego z niego korzystania, kontynuacja nadmiernego używania smartfona mimo poważnych problemów somatycznych i psychologicznych z tym związanych.

2. Nieprawidłowości w funkcjonowaniu. Obszar ten obejmuje m.in.: (1) nadmierne korzystanie z urządzenia związane z poważnymi, nawracającymi problemami somatycznymi lub psychologicznymi, (2) korzystanie ze smartfona w sytuacjach fizycznie niebezpiecznych, np. podczas przechodzenia przez jezdnię czy prowadzenia samochodu, (3) zagrożenie lub utratę istotnych związków społecznych, pracy, przerwanie nauki z powodu używania smartfona.

3. Kryteria wykluczające, które dotyczą niedokonywania rozpoznania nałogu w przypadku, gdy jest on wtórny do innych zaburzeń psychicznych, np. natręctw ${ }^{17}$.

Przytoczone kryteria nie dają jednak podstawy, by problemowe używanie telefonu komórkowego określić jako uzależnienie. Według I. Grzegorzewskiej i L. Cierpiałkowskiej ${ }^{18}$ brak jest dowodów na neurologiczne podłoże i psychologiczne mechanizmy tego zaburzenia, które byłyby podstawą kwalifikowania ich jako uzależnień substantywnych lub behawioralnych. Mimo to zauważa się rosnący problem racjonalnego używania telefonu komórkowego przez dzieci i młodzież, zwłaszcza w sytuacji, gdy urządzenie stanowi przenośny punkt dostępu do sieci.

${ }^{16}$ Szerzej: T.T.C. Lin, Y.-H. Chiang, Q. Jiang, Sociable People Beware? Investigating Smartphone Versus Nonsmartphone Dependency Symptoms Among Young Singaporeans, ,Social Behavior \& Personality: an International Journal” 2015, nr 43, s. 1209-1216.

${ }^{17}$ P. IZDEBski, M. KotyśKo, Problemowe korzystanie z nowych mediów, s. 253.

18 I. Grzegorzewska, L. CierpiaŁkowska, Uzależnienia behawioralne, s. 241. 
Według J. Billieux i jego współpracowników ${ }^{19}$ zaburzenie może rozwijać się według trzech ścieżek: nadmiernego upewniania się (czyli reasekuracji), impulsywno-antyspołecznej oraz ekstrawertywnej. Szczegółowy ich opis zawiera rysunek 1.

Rysunek 1. Ścieżki powstawania uzależnienia od telefonu komórkowego
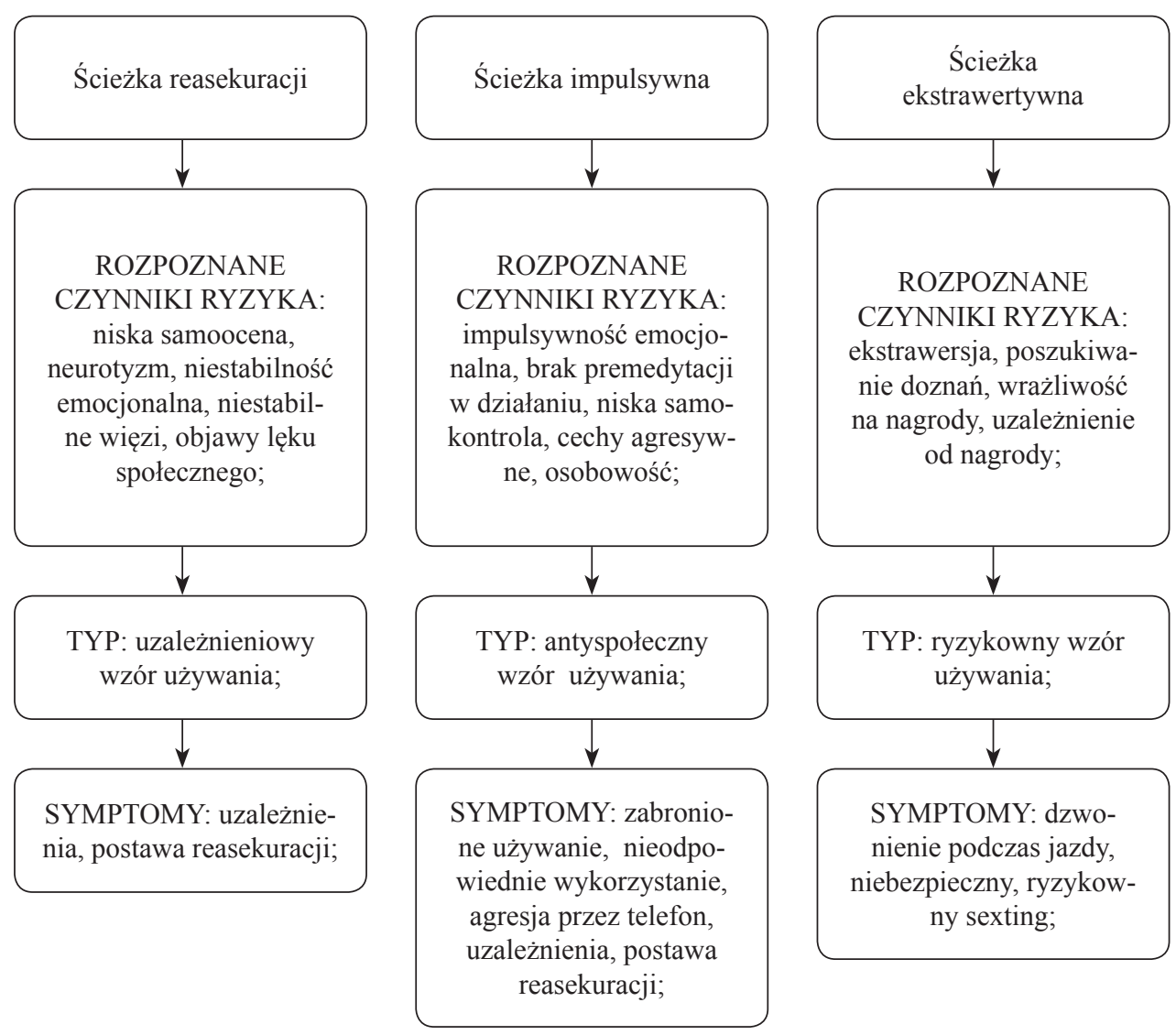

Źródło: opracowanie własne na podstawie J. Billieux, P. Maurage, O. Lopez-Fernandez, D.J. Kuss, M.D.Griffiths, Can disordered mobile phone use be considered a behavioral addiction? An update on current evidence and a comprehensive model for future research, „Current Addiction Reports 2” 2015, nr 2, s. 156-162

19

J. Billieux, P. Maurage, O. Lopez-Fernandez, D.J. Kuss, M.D.Griffiths, Can disordered mobile phone use be considered a behavioral addiction? An update on current evidence and a comprehensive model for future research, „Current Addiction Reports ” 2(2015), nr 2, s. 156-162. 


\subsection{KONTROLA RODZICIELSKA UŻYWANIA PRZEZ DZIECI NOWYCH TECHNOLOGII CYFROWYCH}

Jednym z podstawowych zadań rodziców jest opieka nad swoimi dziećmi. Powinna ona przejawiać się m.in. dbałością o ich rozwój społeczny i stwarzaniem możliwości osiągnięcia przez nich sukcesu w życiu. T. Szlendak ${ }^{20}$ wskazuje, że to $\mathrm{w}$ ramach socjalizacji w rodzinie występuje sterowanie zachowaniami dzieci i kształtowanie ich postaw, a to możliwe jest dzięki np. sprawowaniu kontroli nad ich zachowaniem. Chodzi tutaj o kontrolę w znaczeniu społecznym, czyli zespół sposobów i środków działania określonej rodziny jako grupy społecznej, zmierzający za pomocą sankcji do zapewnienia zwartości i określonego funkcjonowania jej członków.

Istnieje wiele technik kontroli rodzicielskiej. W literaturze przedmiotu wymienia się głównie system nagród i kar, których stosowanie zależy m.in. od pochodzenia rodziców, ich zwyczajów i propagowanych wzorów zachowań ${ }^{21}$. Zatem to na ojcu i matce spoczywa obowiązek w pierwszej kolejności kształtowania bezpiecznego korzystania $\mathrm{z}$ nowych technologii cyfrowych, a dopiero potem ich kontrolowania celem utrwalenia i propagowania $\mathrm{w}$ dorosłym życiu.

E. Krzyżak-Szymańska podzieliła formy kontroli rodzicielskiej w zakresie dostępu dzieci i młodzieży do urządzeń cyfrowych na dwie grupy: pasywną (dyrektywną i restrykcyjną) oraz aktywną (bezpośrednią i pośrednią). Ich szczegółowy opis znajduje się na rysunku 2.

${ }^{20}$ T. Szlendak, Socjologia rodziny. Ewolucja, historia, zróżnicowanie, Warszawa: Wydawnictwo Naukowe PWN 2010, s. 232.

${ }^{21}$ M. Łoвоскі, ABC wychowania, Lublin: Wydawnictwo UMCS 2003, s. 106-112. 
Rysunek 2. Formy kontroli rodzicielskiej stosowane w zakresie dostępu dzieci i młodzieży do urządzeń cyfrowych

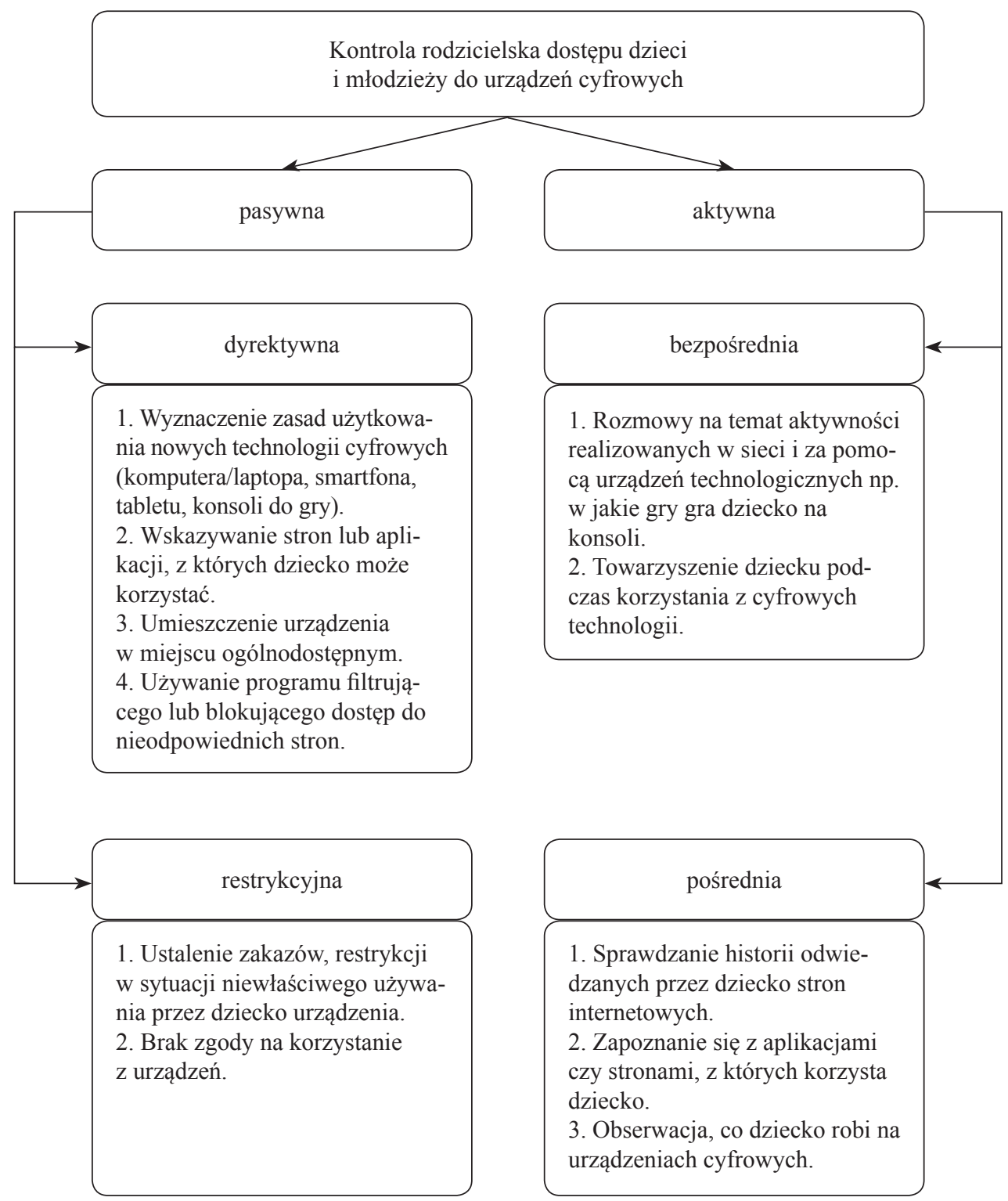

Źródło: E. Krzyżak-Szymańska, Uzależnienia technologiczne wśród dzieci i młodzieży. Teoria, profilaktyka, terapia- wybrane zagadnienia, Kraków: Impuls 2018, s. 159 
Natomiast M. Dębski na podstawie zrealizowanych badań „Nałogowe korzystanie z telefonów komórkowych” wskazuje, „iż częstotliwość i długość korzystania z urządzeń mobilnych rośnie wraz z wiekiem choćby dlatego, że maleje kontrola rodzicielska i rośnie wpływ grupy rówieśniczej”22.

\section{GRUPA BADANA I METODA}

W badaniach ${ }^{23}$ wzięła udział młodzież w wieku od 12 do 19 lat, która w roku szkolnym 2016/2017 uczęszczała do szkół gimnazjalnych i ponadgimnazjalnych zlokalizowanych na terenie województwa śląskiego. Dobór osób do próby był losowy - wielowarstwowy. Łącznie przebadano 2657 osób. Największy odsetek wśród badanych stanowili uczniowie gimnazjów (50\%; $N=1326)$, najmniejszy zaś uczniowie szkół zawodowych $(13 \% ; N=340)$. W badanej próbie licealiści obejmowali $20 \%(N=527)$, zaś uczniowie techników $17 \%(N=464) .43 \%$ respondentów było płci żeńskiej $(N=1143)$, a 57\% męskiej $(N=1514)$. Analizując aktywność zawodową rodziców badanych uczniów, ustalono, że 82\% ojców i 75\% matek ankietowanych pracuje zawodowo.

W badaniach posłużono się adaptowaną do polskich warunków Skalą Problematycznego Użytkowania Telefonu Komórkowego dla Młodzieży - Mobile Phone Problem Use Scale for Adolescents (MPPUSA). Skala ta obejmuje 26 itemów, a liczba punktów uzyskanych przez badanych waha się w przedziale od 26 do ok. 260. Odpowiedzi badanych ocenia się na 10-stopniowej skali od opcji: 1 „całkowicie nieprawdziwe” do opcji 10 „całkowicie prawdziwe”. Narzędzie pozwala kwalifikować badaną młodzież w czterech kategoriach: okazjonalnych użytkowników, właściwych użytkowników, ryzykownie używających i problemowo używających telefonu komórkowego.

Schemat określenia dysfunkcjonalnego korzystania z telefonu komórkowego przedstawiono na rysunku 3.

22 M. DĘвSKI, Nałogowe korzystanie z telefonów komórkowych, s. 158.

${ }^{23}$ Prezentowane wyniki badań były częścią projektu finansowanego z Funduszu Rozwiązywania Problemów Hazardowych w ramach I programu Ministra Zdrowia pod nazwą własną Adaptacja $i$ walidacja narzędzia do pomiaru stopnia zagrożenia problematycznym używaniem telefonu komórkowego przez młodzież, Umowa nr 5/HM/2016. 
Rysunek 3. Rozkład punktów uzyskanych w Skali Problematycznego Używania Telefonu Komórkowego przez Młodzież (MPPUSA) w polskiej adaptacji E. Krzyżak-Szymańskiej

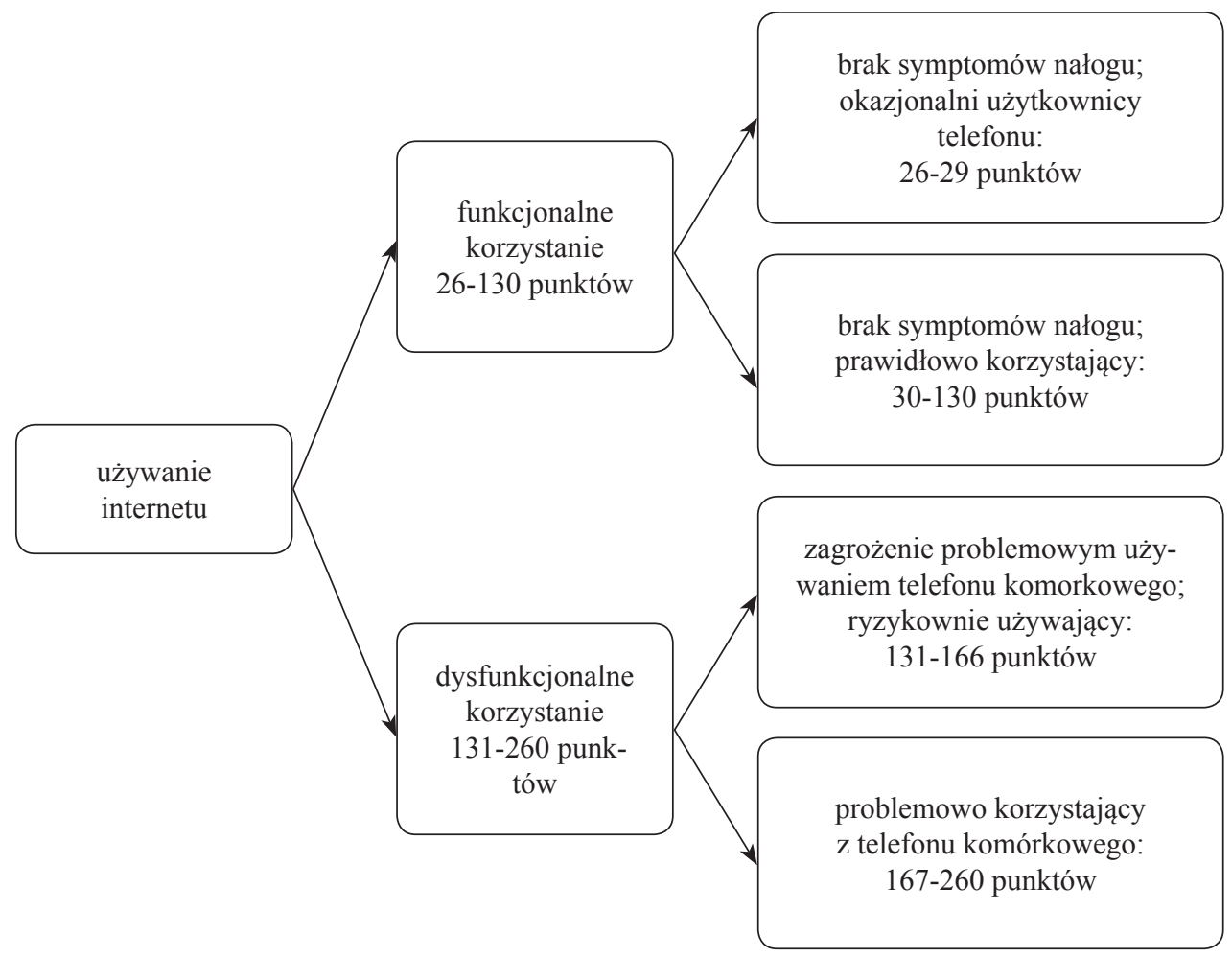

Źródło: Opracowanie własne

W badaniach zastosowano ponadto autorski kwestionariusz ankiety ${ }^{24}$ składający się z 38 pytań. W artykule wykorzystano jedynie część z nich, analizując obszary identyfikujące aktywności podejmowane przez respondentów za pomocą telefonu komórkowego oraz aspekty kontroli rodzicielskiej używania urządzenia przez badanych.

Badania były anonimowe. Zrealizowano je online za pomocą portalu ankietka.pl. Do analizy statystycznej wyników wykorzystano program statystyczny SPSS-24.

${ }^{24}$ Kwestionariusz ankiety przygotował zespół badawczy w składzie: E. Krzyżak-Szymańska, K. Warzecha, A. Szymański. 


\section{ANALIZA WYNIKÓW BADAŃ}

Zebrane dane z próby $(N=2657)$ wskazują, że $44 \%$ badanych $(N=1181)$ wykazuje cechy dysfunkcjonalnych użytkowników telefonów komórkowych. Wśród nich:

$-6 \%$ respondentów $(N=158)$ to osoby problemowo używające telefonu komórkowego,

- 38\% badanych $(N=1023)$ to uczniowie zagrożeni problemowym korzystaniem z urządzenia.

Natomiast $56 \%$ próby $(N=1476)$ to badani właściwie użytkujący telefon komórkowy, w tym 9\% $(N=227)$ okazjonalnie wykorzystujący urządzenie.

Ustalono, że średni wynik ogólny testu wyniósł 84 punkty ${ }^{25}$. Jest on istotnie wyższy wśród badanych dziewcząt niż chłopców. U dziewcząt wynosił 91 punktów, a u chłopców 79 punktów. Choć średni wynik testu wśród respondentów różnił się ze względu na ich wiek (patrz rysunek 4) to różnice między średnimi w tych podgrupach nie były statystycznie istotne.

Rysunek 4. Średnia liczba punktów uzyskana przez respondentów z skali MPPUSA z podziałem na wiek

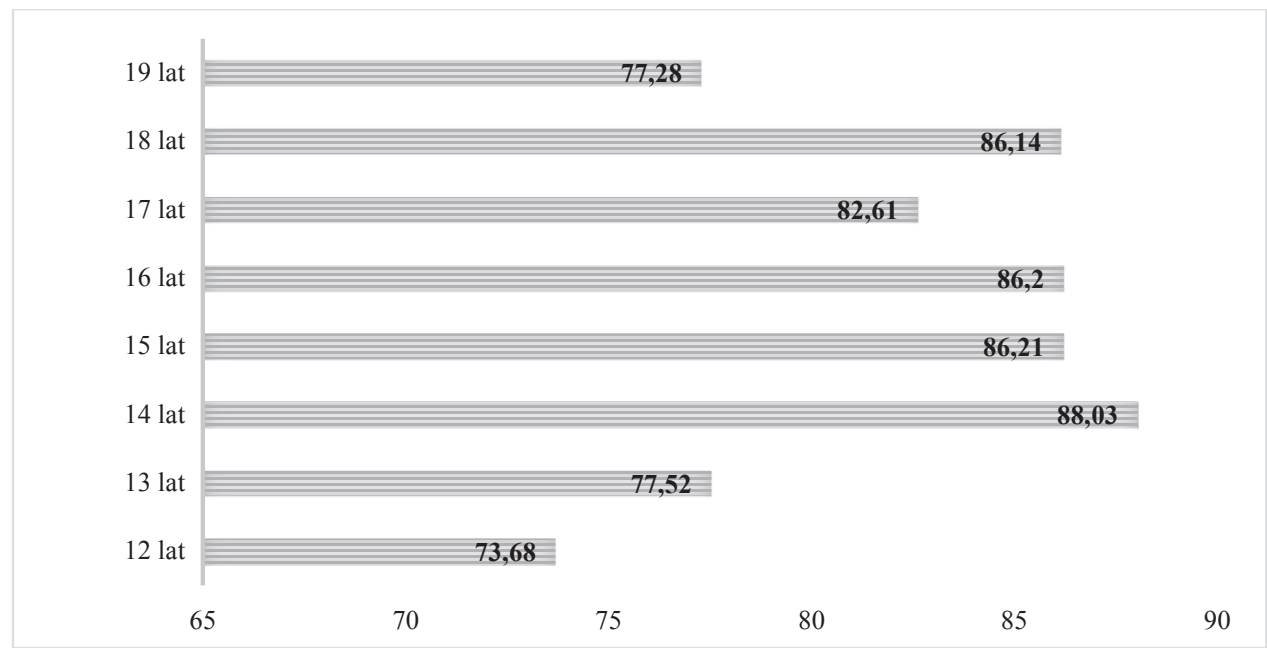

Źródło: Badania własne

${ }^{25}$ Wynik testu może przybierać wartości od 20 do 260. 
W dalszej części starano sią określić, jakie aktywności respondenci najczęściej realizują za pomocą telefonu komórkowego. Szczegółowy wykaz funkcji, $\mathrm{z}$ jakich korzystają respondenci prezentuje tabela 1.

Tabela 1. Wykorzystanie funkcji telefonu komórkowego i częstotliwość ich użycia wśród uczniów gimnazjów i szkół ponadgimnazjalnych województwa śląskiego (dane w \%)

\begin{tabular}{|l|c|c|c|l|}
\hline \multirow{2}{*}{\multicolumn{1}{|c|}{ Gimnazjaliści }} & \multicolumn{2}{|c|}{$\begin{array}{c}\text { Częstotliwość realizacji funkcji } \\
\text { telefonu komórkowego }\end{array}$} & \multirow{2}{*}{$\begin{array}{c}\text { Uczniowie szkoły } \\
\text { ponadgimnazjalnej }\end{array}$} \\
\cline { 2 - 4 } & $\begin{array}{c}\text { codziennie } \\
\text { lub prawie } \\
\text { codziennie }\end{array}$ & Lp. & $\begin{array}{c}\text { codziennie } \\
\text { lub prawie } \\
\text { codziennie }\end{array}$ & \\
\hline $\begin{array}{l}\text { do sprawdzania czasu, } \\
\text { godziny }\end{array}$ & 76,46 & 1 & 80,79 & do sprawdzania czasu, godziny \\
\hline do korzystania z Internetu & 66,15 & 2 & 75,37 & do korzystania z Internetu \\
\hline $\begin{array}{l}\text { do korzystania z portali } \\
\text { społecznościowych, np. FB, } \\
\text { Instagram, Twitter, Snapchat }\end{array}$ & 61,78 & 3 & 71,81 & $\begin{array}{l}\text { do korzystania z portali społecz- } \\
\text { nościowych, np. FB, Instagram, } \\
\text { Twitter, Snapchat }\end{array}$ \\
\hline do słuchania muzyki & 54,26 & 4 & 71,21 & do korzystania z budzika \\
\hline do korzystania z budzika & 50,23 & 5 & 63,08 & do słuchania muzyki \\
\hline do rozmów telefonicznych & 37,26 & 6 & 47,52 & do wysyłania SMS-ów/ MMS-ów \\
\hline $\begin{array}{l}\text { do wysyłania SMS-ów/ } \\
\text { MMS-ów }\end{array}$ & 31,86 & 7 & 43,85 & do rozmów telefonicznych \\
\hline do robienia zdjęć & 29,69 & 8 & 32,51 & do robienia zdjęć \\
\hline
\end{tabular}

Źródło: Badania własne

Jak wynika $\mathrm{z}$ danych zawartych w tabeli 1, ponad połowa badanych korzysta z tych funkcji telefonu, które pozwalają na zastępowanie takich urządzeń jak budzik, zegarek czy odtwarzacz muzyki. Natomiast 2/3 badanych uczniów wykorzystuje telefon jako punkt dostępu do sieci.

Chcąc ustalić związek między dysfunkcjonalnym korzystaniem z telefonu komórkowego przez badanych a realizowaną wobec nich kontrolą rodzicielską w zakresie użytkowania telefonu, w pierwszej kolejności określono, czy rodzice w ogóle takie działania podejmują.

Należy zaznaczyć, że odpowiedzi udzielali sami uczniowie, co wskazuje, że odnosili się oni tylko do tych form kontroli, o których wiedzieli, że są wobec nich stosowane. Dziewięciu na dziesięciu badanych stwierdzało, że rodzice nie stosują wobec nich żadnych form kontroli rodzicielskiej używania przez nich telefonu komórkowego. Natomiast 10\% chłopców i 12\% dziewcząt opisuje kontrolowanie ich przez rodziców w zakresie korzystania z telefonu komórkowego. W celu sprawdzenia istotności związku między płcią respondenta a stosowaniem wobec niego kontroli rodzicielskiej przeprowadzono test niezależności dwóch zmiennych $-\chi^{2}$. Istotny wynik testu pozwolił na odrzucenie hipotezy zerowej 
i przyjęcie hipotezy alternatywnej o swoistym związku między analizowanymi zmiennymi $\chi^{2}(1, N=2657)=2,65 ; p<0,01$. Siła związku między analizowanymi zmiennymi mierzona statystyką $\varphi$ byta nikta $i$ wynosita $\varphi=0,032 ; p<0,01$. $\mathrm{W}$ podobny sposób zbadano istotność statystyczną związku pomiędzy wiekiem dziecka a stosowaniem kontroli rodzicielskiej. Stwierdzono, że związek taki występuje $\left(\chi^{2}(8, N=2657)=78,57 ; p<0,01\right.$, a jego siła między analizowanymi zmiennymi mierzona statystyką V Kramera była bardzo słaba i wynosiła 0,$172 ; p<0,01$. Zauważono, że wraz $\mathrm{z}$ wiekiem badanych sukcesywnie spada odsetek uczniów deklarujących kontrolowanie przez rodziców ich aktywności z wykorzystaniem telefonu komórkowego i tak 19\% dwunastolatków i tylko 5\% dziewiętnastolatków dostrzega aktywność rodziców w omawianym zakresie.

Ponadto zbadano, czy istnieje statystycznie istotny związek między dysfunkcjonalnym korzystaniem przez badanych z telefonu komórkowego a sprawowaniem kontroli rodzicielskiej (w zakresie używania przez badanych przedmiotowego urządzenia). Przeprowadzono test niezależności dwóch zmiennych $-\chi^{2}$. Istotny wynik testu pozwolił na odrzucenie hipotezy zerowej i przyjęcie hipotezy alternatywnej o swoistym związku między analizowanymi zmiennymi $\chi^{2}(1, N=2657)=4,21$; $p<0,01$. Siła związku między analizowanymi zmiennymi mierzona statystyką $\varphi$ była bardzo słaba i wynosiła $\varphi=-0,04 ; p<0,01$. Ponieważ współczynnik korelacji $\varphi$ był ujemny, można wskazać, że wraz z nasileniem się symptomów dysfunkcjonalnego korzystania przez badanych z telefonu komórkowego maleje liczba rodziców stosujących kontrolę rodzicielską w przedmiotowym zakresie.

Następnie określono, czy stosowanie przez rodziców kontroli rodzicielskiej ma istotny statystycznie związek z aktywnościami dzieci realizowanymi za pomocą telefonu komórkowego. Ustalono, że uczniowie, wobec których rodzice stosują kontrolę rodzicielską użytkowania telefonu komórkowego, istotnie statystycznie rzadziej korzystają z internetu w telefonie $\left(\chi^{2}(4, N=2657)=11,36 ; p<0,01\right)$, łączą się za jego pomocą z portalami społecznościowymi $\left(\chi^{2}(4, N=2657)=9,57\right.$; $p<0,01)$ i słuchają muzyki $\left(\chi^{2}(4, N=2657)=18,81 ; p<0,01\right)$. Związek ten jednak jest bardzo słaby, a statystyka V Kramera wynosi odpowiednio 0,065, $0,060,0,084 ; \mathrm{p}<0,01$. Natomiast, badani ci istotnie statystycznie częściej wykorzystują organizer $\left(\chi^{2}(4, N=2657)=16,11\right)$ czy budzik $\left(\chi^{2}(4, N=2657)=\right.$ $10,03) \mathrm{w}$ telefonie niż ich koledzy pozbawieni kontroli rodzicielskiej w przedmiotowym zakresie. Mimo występowania tych zależności, ich siła jest bardzo słaba i mierzona statystyka V Kramera wynosi odpowiednio: 0,078 i 0,$061 ; p<0,01$.

Kolejnym elementem istotnym w podjętych analizach było określenie form kontroli rodzicielskiej stosowanej wobec badanych. W grupie osób, które deklarowały występowanie w ich rodzinach kontroli używania telefonu komórkowego $(N=266)$, określono, jakie były to formy kontroli. Badani uczniowie wymieniali 
różne sposoby kontrowania, począwszy od zainstalowania programu filtrującego, ustalania czasu i warunków korzystania z urządzenia, jak i zakazów jego wykorzystywania, np. do grania w gry. Wykazane przez respondentów sposoby kontroli rodzicielskiej pogrupowano na formy pasywne i aktywne. Szczegółowy podział form kontroli rodzicielskiej przedstawia rysunek 5 .

Rysunek 5. Formy kontroli rodzicielskiej stosowane wobec respondentów

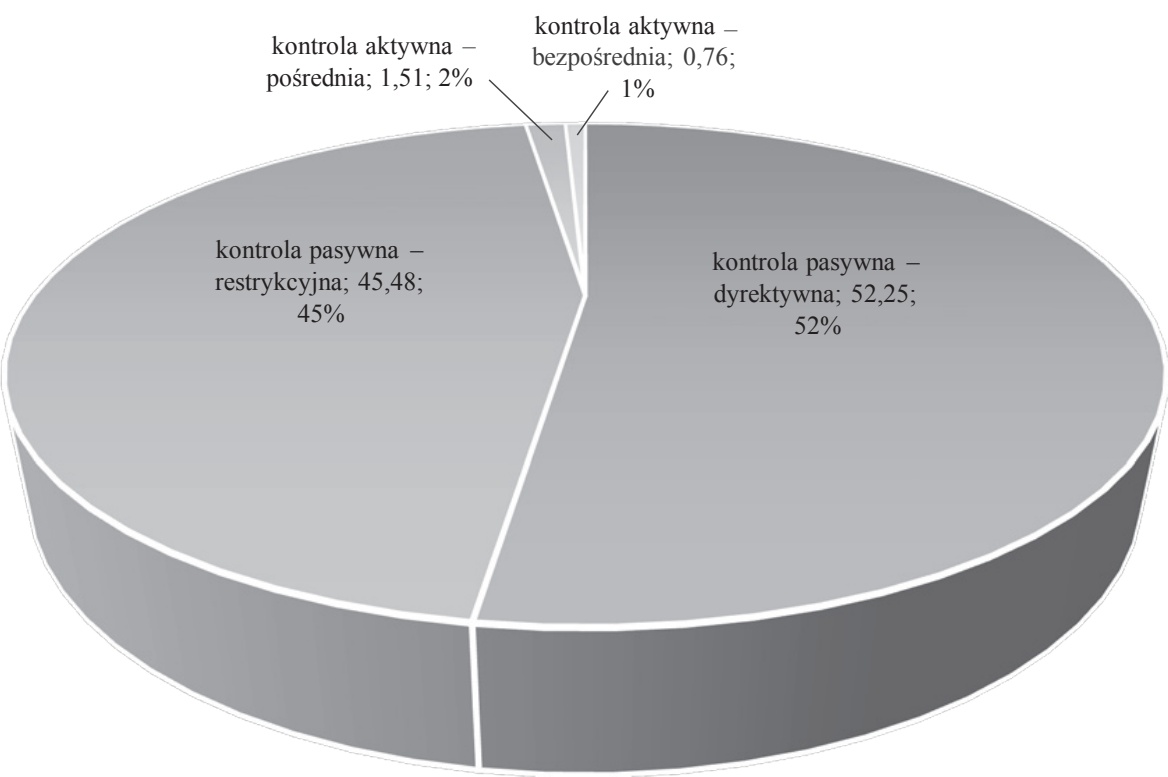

Źródło: Badania własne

Jak wynika z przeprowadzonych analiz, ani płeć, ani wiek nie różnicuje istotnie statystycznie form kontroli rodzicielskiej stosowanej wobec dzieci.

Dodatkowo sprawdzono, czy istnieje zależność między formą stosowanej kontroli rodzicielskiej korzystania z telefonu komórkowego a poziomem dysfunkcjonalnego używania przez dziecko urządzenia. Ustalono, że występuje istotna statystycznie zależność między wymienionymi zmiennymi $\chi^{2}(1, N=266)=4,15$; $p<0,01$. Siła związku między nimi mierzona statystyką $\varphi$ była słaba i wynosiła $\varphi=-0,245 ; p<0,01$. Powyższe wyniki wskazują, że rodzice, którzy stosują kontrolę wobec używania przez dzieci telefonu komórkowego wykorzystują tym częściej jej formy pasywne, im bardziej dziecko przejawia dysfunkcjonalne używanie przedmiotowego urządzenia. 


\section{PODSUMOWANIE}

Coraz częściej zauważamy, że młode pokolenie nadużywa technologii cyfrowych, w tym w szczególności telefonu komórkowego. To właśnie telefon komórkowy stał się mobilnym punktem dostępowym do sieci, pozwalającym młodzieży na realizację szeregu codziennych aktywności. Istotną rolę w kształtowaniu właściwego użytkowania omawianego urządzenia mają rodzice i sprawowana przez nich kontrola rodzicielska. Wśród badanych uczniów tylko co dziesiąty wskazywał, że rodzice kontrolują jego zachowania dotyczące użytkowania telefonu. Pozostali nie byli w ogóle kontrolowani lub byli tego nieświadomi.

Brak kontroli rodzicielskiej ze strony ojca czy matki jest poważnym problemem współczesnej rodziny. Powoduje on lukę w procesie socjalizacji do korzystania z nowych mediów realizowanym w domu rodzinnym. Jest ona tym bardziej istotna, że $44 \%$ badanych uczniów dysfunkcjonalnie korzysta z telefonu komórkowego. Z prezentowanych badań wynika statystycznie istotny związek między poziomem dysfunkcjonalności używania telefonu komórkowego przez młodzież a realizowaniem przez rodziców wobec nich kontroli rodzicielskiej (w zakresie używania przedmiotowego urządzenia).

$\mathrm{Z}$ analizy danych wynika, że dziewczęta są częściej kontrolowane przez rodziców, a omawiane oddziaływanie zmniejsza swoją częstotliwość wraz z wiekiem respondenta. Ustalono, że istnieje istotny statystycznie związek, choć o bardzo słabej sile, między płcią i wiekiem respondenta a stosowaniem wobec niego kontroli rodzicielskiej.

Rodzice, którzy stosują wobec badanej młodzieży kontrolę rodzicielską, najczęściej wykorzystują formy kontroli pasywnej (97\%). Tylko 3\% rodziców stara się realizować jej aktywne formy. Jak wynika z przeprowadzonych analiz, ani płeć, ani wiek dziecka nie różnicuje istotnie statystycznie form kontroli rodzicielskiej stosowanej wobec niego. Można przypuszczać, że jest to wynik braku wiedzy rodziców na temat aktywnych form kontroli i ich skuteczności.

Uzyskane wyniki pozwalają na postulowanie zmian w zakresie pedagogizacji rodziców realizowanej m.in. przez szkołę. Zmiany te powinny obejmować:

1. Edukację rodziców w zakresie skutecznych form kontroli rodzicielskiej korzystania przez dzieci z nowych mediów, w szczególności z telefonu komórkowego.

2. Instruktaż instalowania i stosowania technicznych narzędzi kontroli rodzicielskiej.

3. Wyposażenie rodziców w kompetencje cyfrowe na takim poziomie, aby mogli efektywnie podejmować działania zabezpieczające ich dzieci przed zagrożeniami wynikającymi z nadużywania urządzeń cyfrowych. 


\section{BIBLIOGRAFIA}

Bianchi A., Phillips J.G., Psychological predictors of problem mobile phone use, „Cyberpsychology \& Behavior" 2005, nr 8, s. 39-51.

Billieux J., Maurage P., Lopez-Fernandez O., Kuss D.J., Griffiths M.D, Can disordered mobile phone use be considered a behavioral addiction? An update on current evidence and a comprehensive model for future research, „Current Addiction Reports” 2015, nr 2, s. 156-162.

DęBSKi M., Nałogowe korzystanie z telefonów komórkowych. Raport z badań, Gdańsk: Fundacja Dbam o swój zasięg 2016.

Grzegorzewska I., Cierpiąkowska L., Uzależnienia behawioralne, Warszawa: Wydawnictwo Naukowe PWN 2018.

IzDebski P., Koтүśko M., Problemowe korzystanie z nowych mediów, w: Zaburzenia uprawiania hazardu i inne tak zwane nałogi behawioralne, red. B. Habrat, Warszawa: Instytut Psychiatrii i Neurologii 2016, s. 219-304.

Johnson G.M., Internet Use and Child Development: The Techno-Microsystem, „Australian Journal of Educational \& Developmental Psychology" 2010, nr 10, s. 32-43.

Johnson G.M., Puplampu K.P., Internet Use during Childhood and the Ecological Techno-Subsystem, „Canadian Journal of Learning and Technology” 2008, nr 34, s. 19-28.

KRZYŻAK-SZYMańsKa E., Norma i patologia w użytkowaniu przez digital natives nowych technologii cyfrowych, w: Tváre l’udského života. Vybrané problémy, red. W. Kądziołka, Ružomberok: Verbum-vydavatel'stvo KU 2015, s. 129-168.

KRZYŻAK-SzYMAŃSKa E., Uzależnienia technologiczne wśród dzieci i młodzieży. Teoria, profilaktyka, terapia - wybrane zagadnienia, Kraków: Impuls 2018.

Lin T.T.C., Chiang Y.-H., Jiang Q., Sociable People Beware? Investigating Smartphone Versus Nonsmartphone Dependency Symptoms Among Young Singaporeans, „Social Behavior \& Personality: an International Journal” 2015, nr 43, s. 1209-1216.

Lin Y.-H., Chang L.-R., Lee Y.-H., Tseng H.-W., Kuo T.B.J., Chen S.-H., Development and Validation of the Smartphone Addiction Inventory (SPAI), „PLoS ONE” 2014, nr 9(6), s. e98312.

ŁовоскI M., ABC wychowania, Lublin: Wydawnictwo UMCS 2003.

Lopez-Fernandez O., Honrubia-Serrano L., Freixa-Blanxart M., Prevalence of problematic mobile phone use in British adolescents, „CyberPsychology, Behavior and Social Networking” 2014, nr 17, s. 91-98.

PawŁowska B., Potembska E., Objawy zagrożenia i uzależnienia od telefonu komórkowego mierzonego Kwestionariuszem do Badania Uzależnienia od Telefonu Komórkowego, autorstwa Potembskiej i Pawłowskiej u młodzieży w wieku od 13 do 24 lat, „Current Problems of Psychiatry" 2011, nr 12, s. 443-446.

Pourrazavi S., Allahverdipour H., Jafarabadi M.A., Matlabi H., A socio-cognitive inquiry of excessive mobile phone use, „Asian Journal of Psychiatry” 2010, nr 10, s. 84-89.

Sahin S., Ozdemir K., Unsal A., Temiz N., Evaluation of Mobile Phone Addiction Level and Sleep Quality in University Students, „Pakistan Journal of Medical Sciences” 2013, nr 29, s. 913-918.

Szlendak T., Socjologia rodziny. Ewolucja, historia, zróżnicowanie, Warszawa: Wydawnictwo Naukowe PWN 2010.

TNS PolsKa S.A., Rodzice i dzieci wobec zagrożeń dzieci w Internecie, Warszawa: Fundacja Orange 2016. 


\section{DYSFUNKCJONALNE UŻYWANIE TELEFONU KOMÓRKOWEGO WŚRÓD MŁODZIEŻY A KONTROLA RODZICIELSKA}

\section{Streszczenie}

Dynamiczny rozwój nowych technologii cyfrowych i coraz powszechniejsze ich użycie w codziennym życiu powodują, że badacze zastanawiają się nad ich wpływem na rozwój człowieka i jego funkcjonowanie społeczne. Szczególne miejsce wśród tych urządzeń odgrywa telefon komórkowy (smartfon), który obecnie nie służy już tylko celom komunikacyjnym, ale jest swoistym mobilnym centrum dowodzenia. Dlatego też badacze starają się wyjaśnić, kiedy używanie telefonu staje się dysfunkcjonalne i jakie są przyczyny tego stanu rzeczy. Jednym z czynników środowiskowych mających wpływ na rozwój nałogu jest kontrola rodzicielska sprawowana przez matkę i ojca w zakresie używania przez dziecko telefonu komórkowego.

Artykuł przedstawia wyniki badań młodzieży dysfunkcjonalnie używającej telefonu komórkowego w kontekście kontroli rodzicielskiej realizowanej przez opiekunów w obszarze użytkowania nowych mediów. Analizie interpretacyjnej poddano wyniki 2657 uczniów szkół gimnazjalnych i ponadgimnazjalnych województwa śląskiego w wieku 12-19 lat. Dobór osób do próby był losowy - wielowarstwowy.

Metoda. W badaniach wykorzystano Skalę Problematycznego Użytkowania Telefonu Komórkowego dla Młodzieży, Mobile Phone Problem Use Scale for Adolescents (MPPUSA) oraz autorski kwestionariusz ankiety.

Wyniki. Stwierdzono istotny statystycznie (chociaż słaby) związek między poziomem dysfunkcjonalnego używania telefonu komórkowego respondenta a realizowaną wobec niego kontrolą rodzicielską w zakresie korzystania z urządzenia.

Słowa kluczowe: uzależnienia technologiczne; problemowe używanie telefonu komórkowego; kontrola rodzicielska. 